Article

\title{
The Circular Economy Approach to Improving CNP Ratio in Inland Fishery Wastewater for Increasing Algal Biomass Production
}

\author{
Janet B. García-Martínez ${ }^{1,2}$, Leidy P. Sanchez-Tobos ${ }^{2}$, Nicolaz A. Carvajal-Albarracín ${ }^{2}$, \\ Andrés Fernando Barajas-Solano ${ }^{2}\left(\mathbb{D}\right.$, Crisostomo Barajas-Ferreira ${ }^{1}$, Viatcheslav Kafarov ${ }^{1}$ and Antonio Zuorro ${ }^{3, *(D)}$ \\ 1 Program of Chemical Engineering, Research Center for Sustainable Development in Industry and Energy, \\ Universidad Industrial de Santander, Bucaramanga 680003, Colombia; \\ janet2138032@correo.uis.edu.co (J.B.G.-M.); cbarajas@uis.edu.co (C.B.-F.); kafarov@uis.edu.co (V.K.) \\ 2 Department of Environmental Sciences, Universidad Francisco de Paula Santander, Av. Gran Colombia, \\ No. 12E-96, Cucuta 540003, Colombia; leidypaolast@ufps.edu.co (L.P.S.-T.); \\ nicolazalejandroca@ufps.edu.co (N.A.C.-A.); andresfernandobs@ufps.edu.co (A.F.B.-S.) \\ 3 Department of Chemical Engineering, Materials and Environment, Sapienza University, Via Eudossiana 18, \\ 00184 Roma, Italy \\ * Correspondence: antonio.zuorro@uniroma1.it
}

check for updates

Citation: García-Martínez, J.B.; Sanchez-Tobos, L.P.; CarvajalAlbarracín, N.A.; Barajas-Solano, A.F.; Barajas-Ferreira, C.; Kafarov, V.; Zuorro, A. The Circular Economy Approach to Improving CNP Ratio in Inland Fishery Wastewater for Increasing Algal Biomass Production. Water 2022, 14, 749. https://doi.org/ 10.3390/w14050749

Academic Editor: Feng-Min Li

Received: 29 December 2021

Accepted: 24 February 2022

Published: 26 February 2022

Publisher's Note: MDPI stays neutral with regard to jurisdictional claims in published maps and institutional affiliations.

Copyright: (c) 2022 by the authors. Licensee MDPI, Basel, Switzerland. This article is an open access article distributed under the terms and conditions of the Creative Commons Attribution (CC BY) license (https:// creativecommons.org/licenses/by/ $4.0 /)$.

\begin{abstract}
In this work, the capacity of wastewater from an inland fishery system in Colombia (Norte de Santander) was tested as culture medium for Chlorella sp. and Scenedesmus sp. Due to insufficient $\mathrm{N}$ and $\mathrm{P}$ concentrations for successful algae growth, the effect of wastewater replenishment with $\mathrm{NO}_{3}$, $\mathrm{PO}_{4}$, and $\mathrm{Na}_{2} \mathrm{CO}_{3}$ or $\mathrm{NaHCO}_{3}$ as a carbon source was analyzed using a three-factor nonfactorial response surface design. The results showed that the addition of $\mathrm{NaNO}_{3}(0.125 \mathrm{~g} / \mathrm{L}), \mathrm{K}_{2} \mathrm{HPO}_{4}$ $(0.075 \mathrm{~g} / \mathrm{L}), \mathrm{KH}_{2} \mathrm{PO}_{4}(0.75 \mathrm{~g} / \mathrm{L})$, and $\mathrm{NaHCO}_{3}(0.5$ and $2 \mathrm{~g} / \mathrm{L}$ for Chlorella sp. and Scenedesmus sp. respectively) significantly increased the biomass of Chlorella sp. $(0.87 \mathrm{~g} / \mathrm{L})$ and Scenedesmus $\mathrm{sp}$. $(0.83 \mathrm{~g} / \mathrm{L})$. Although these results show that the addition of other nutrients is not necessary $(\mathrm{Na}, \mathrm{Mg}$, $\mathrm{SO}_{4}, \mathrm{Ca}$, etc.), it is still essential to determine the quality of the biomass produced in terms of its application as a feed supplement for fish production.
\end{abstract}

Keywords: Oreochromis sp.; protein; lipids; carbohydrates; Scenedesmus; Chlorella; inland fisheries

\section{Introduction}

Fish production is the source of animal protein with the highest growth rate; according to the Food and Agriculture Organization of the United Nations (FAO), between 2001 and 2018 , aquaculture production grew by $5.3 \%$, while fish consumption significantly increased to $19.4 \mathrm{~kg}$ per capita in 2017 [1]. This growth in both processing and consumption is attributed to their capacity to successfully provide safe food with a higher micronutrient yield with less environmental input [2].

Aquaculture production can be separated into two main categories, open (with constant water exchange) and closed systems (without water exchange) [3]. In the last few years, the inland open system has become an economical option for producing high-quality fish protein in Africa and Latin America, strengthening fish production on both continents $[4,5]$. However, its large water exchange volume has led to an elevated demand for freshwater and a high concentration of wastewater with significant levels of dissolved inorganic nitrogen and phosphorus that must be safely treated before its disposition [6]; however, a large volume of the wastewater is not treated correctly [7]. Such high levels of nutrients are caused by relatively high fish stocking densities, intensive feeding regimes, and leftovers of uneaten food. According to Crab et al. [8], up to $75 \%$ of food consumed is converted to nitrogen and phosphorus. The latter contributes to the sustained increase in organic residues and toxic compounds in aquatic systems [9]. Nutrients such as nitrogen 
and phosphorus are the main ones responsible for eutrophication in water bodies nearby fishery production sites [10]; therefore, the removal of those nutrients is a critical step to prevent negative impacts on the local water environments [11].

The biological denitrification of nitrate in aquaculture wastewater is an efficient process that depends on using organic matter inside the wastewater as a carbon source [12].

Unlike open systems, which require a constant water exchange, recirculation aquaculture systems (RASs) or "closed systems" are based on the treatment of post-consumption water for its subsequent re-entry into the culture ponds [13]. This system has the quality of reducing the water footprint in a sustained manner [14], while generating a solid residue (sludge) that can be used as a matrix for biogas production [15].

During the last 50 years, significant efforts have been made to remove different nutrients from this wastewater to avoid eutrophication of water bodies near the production systems and recirculate the treated water [8]. Currently, there is a great diversity of biological and chemical methods that have been used satisfactorily in the nutrient removal process, such as (1) biological processes for nitrogen removal including nitrification and denitrification [16] and (2) chemical processes including chemical precipitation for phosphorus removal [17]; the latter process, despite being helpful, is a less environmentally friendly technique since it leads to the formation of sludge that is highly polluting to the environment [18]. One alternative is the biological treatment of wastewater using microalgal cultures [19]. The use of microalgae and cyanobacteria is considered one of the most prominent technologies with the most significant contribution to the conservation of the environment [9]. This is due to their fast growth rate. They can grow in wastewater while reducing the concentration of harmful nutrients; moreover, their biomass can be used as feedstock for a wide range of industrial interest products [20].

The research and development on the application of aquaculture liquid waste as a source of nutrients to produce algal-based metabolites is a field that, in recent years, has attracted different researchers worldwide. Figure 1 shows the number of publications in the last 22 years (TITLE-ABS-KEY: aquaculture AND wastewater AND microalga), according to the Scopus database (Elsevier). It is possible to observe that, since 2012, the number of documents has exponentially increased up to a final number of 121 (including accepted manuscripts for 2022). China, Malaysia, the United States, and India dominate the scientific publication on the usage of aquacultural wastewater into usable metabolites and biomass.

Through the culture of microalgae into the wastewater, it is possible to remove the concentrations of nitrates, phosphates, and other nutrients present to obtain economically viable products for the national aquaculture sector, such as (1) protein and fat-rich feed, (2) biofertilizers, and (3) biofuels [18]. To date, the use of different strains of microalgae and cyanobacteria such as Chlamydomonas sp. [21], Chlorella sp. [3,8,22-33], Dunaliella sp. [23,33,34], Isochrysis sp. [33], Nannochloropsis sp. [10,23], Navicula sp. [23], Oscillatoria sp. [26], Parachlorella sp. [35], Platymonas sp. [31,36], Scenedesmus sp. [23,30], Spirulina sp. [37], Synedra sp. [38], Tetraselmis sp. [13,18,23,33,34,39], algal-bacterial biofilm [40], and mixed consortia of algal strains [41] for the removal of nutrients from fishery wastewater has been tested at a laboratory $(<50 \mathrm{~L})$ and demonstration scale $(>200 \mathrm{~L})$ in countries such as Belgium [5,42], China [16], Colombia [43,44], Denmark [41], Spain [15,45], South Africa [22,46], and Poland [19]. One interesting fact from those studies is that most authors worked with wastewater from RAS systems. There are few reports on the utilization of wastewater from inland fisheries with high water exchange rates. The present work evaluates wastewater from inland fisheries with high water exchange as a nutrient source to produce microalgae. 


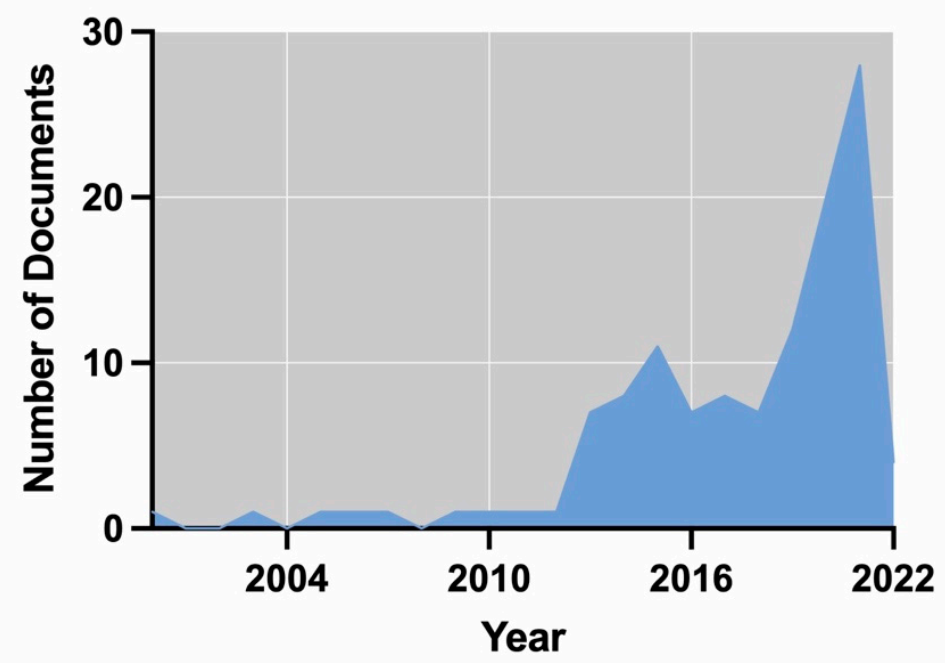

(a)

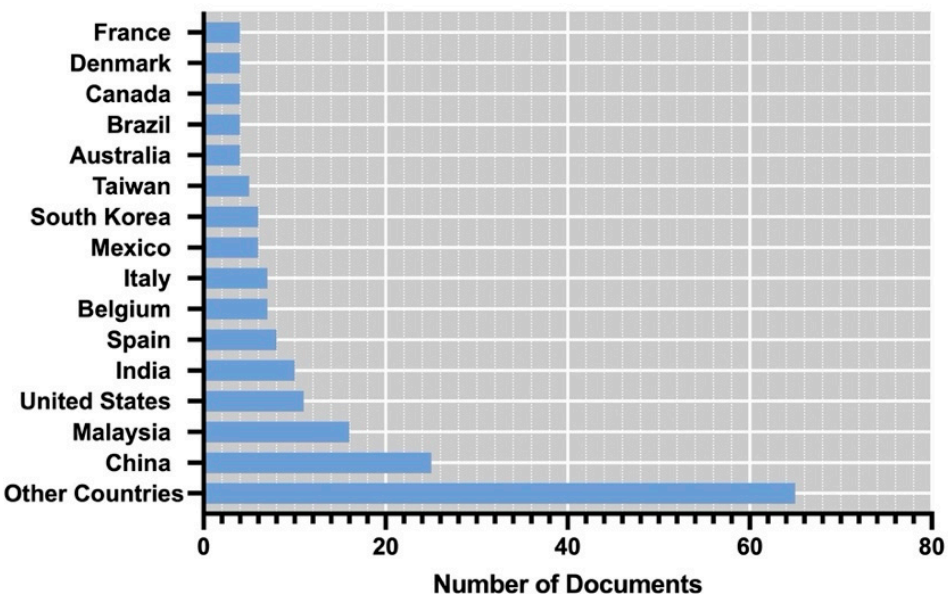

(b)

Figure 1. Evolution of the number of publications from 2000 to 2021 on the transformation of aquacultural wastewater using microalgal biotechnology (a) and their country of origin (b).

\section{Materials and Methods}

\subsection{Fishery Wastewater}

The untreated wastewater used in this study was obtained from a local company (El Manantial) in El Zulia (Norte de Santander, Colombia). The fish production (Oreochromis sp.) is carried out in aerated open ponds with constant water exchange throughout the year. The system uses water from a local river, filtered through a fine-mesh filter with a water replacement rate of $40 \%$ per day. The samples came from the fattening stage with a feed rate of approximately three rations for $7 \mathrm{~g} /$ unit day (approximately $24 \% \mathrm{w} / \mathrm{w}$ of protein, and $2.5 \mathrm{w} / \mathrm{w}$ of lipids) until a culture density of $20-30 \mathrm{fish} / \mathrm{m}^{3}$ was reached. The water was collected through 2019 (February to December) using a sterile amber borosilicate flask and transported at $20^{\circ} \mathrm{C}$. The wastewater was used immediately upon arrival and chemically analyzed $\left(\mathrm{pH}\right.$, turbidity, temperature, $\mathrm{BOD}_{5}, \mathrm{COD}$, total alkalinity, acidity, total hardness, calcium hardness, nitrates, and phosphates) according to standard methods for examining water and wastewater [47].

\subsection{Strains}

Chlorella sp. (CHLO_UFPS010) and Scenedesmus sp. (SCEN_UFPS015) from INNOValgae collection (UFPS, Colombia) were used as inoculate. The strains were pre-cultivated in a 2 L glass flask with a working volume of 1.2 L containing Bold Basal Medium [48]. The 
media was mixed through the injection of filtered air with $0.5 \%(v / v) \mathrm{CO}_{2}$ at a flow rate of $0.78 \mathrm{~L} \cdot \mathrm{min}^{-1}, 25^{\circ} \mathrm{C}$, and a light/dark cycle of $12: 12 \mathrm{~h}$ at $100 \mu \mathrm{mol} \cdot \mathrm{m}^{-2} \cdot \mathrm{s}^{-1}$ for 30 days.

\subsection{Experimental Design}

The fishery wastewater was filtered twice according to Hawrot-Paw [19] and UVsterilized using a device previously designed for this type of wastewater [43]. To identify the best solid inorganic source of carbon that enhanced the production of algal biomass and the removal of $\mathrm{N}$ and $\mathrm{P}$, the wastewater was supplemented with different concentrations $(0.8,1.2$, and $1.6 \mathrm{~g} / \mathrm{L})$ of either sodium carbonate $\left(\mathrm{Na}_{2} \mathrm{CO}_{3}\right)$ or sodium bicarbonate $\left(\mathrm{NaHCO}_{3}\right)$ [44] before inoculation. Both strains were cultured (by triplicate) in a $2 \mathrm{~L}$ glass flask with a working volume of $1.2 \mathrm{~L}$ of UV-sterile wastewater. Each flask was mixed by injection of filtered air at a flow rate of $0.78 \mathrm{~L} \cdot \mathrm{min}^{-1}$ and light/dark cycle of $12: 12 \mathrm{~h}$ at $100 \mu \mathrm{mol} \cdot \mathrm{m}^{-2} \cdot \mathrm{s}^{-1}$ for 30 days. As controls, the strains were cultured in Bold Basal Medium (control BBM) and wastewater without carbon addition (control WW).

The biomass produced was harvested using an electroflotation device (10 aluminum electrodes, $20 \mathrm{~min}, 150 \mathrm{rpm}$, and $50 \mathrm{~W}$ ) [49,50], washed trice with distilled water, freezedried, and stored $\left(4{ }^{\circ} \mathrm{C}\right)$ until use. Lastly, the different components of biomass such as carbohydrates [51,52], proteins [53], lipids [54], carotenoids [55], and ash [56] were measured. The cell-free media were analyzed for their content of nitrates and phosphates.

\subsection{Supplemented Wastewater}

The effect of supplementing the wastewater with $\mathrm{NO}_{3}, \mathrm{PO}_{4}$, and the best carbon source obtained (either $\mathrm{Na}_{2} \mathrm{CO}_{3}$ or $\mathrm{NaHCO}_{3}$ ) was analyzed using a nonfactorial response surface design with three factors, three levels, and two central points.

\section{Results}

\subsection{Fishery Wastewater}

Nutrients such as nitrogen and phosphorus are the main ones responsible for eutrophication in water bodies nearby fishery production sites [10]; therefore, the removal of those nutrients is a critical step to prevent negative impacts on the local water environments $[11,57]$. Wastewater was analyzed for the content of nitrates, phosphates, and other parameters required to identify the quality of the water (Table 1).

Table 1. Physicochemical characteristics of the wastewater.

\begin{tabular}{ccc}
\hline Parameters & Units & Mean Value \\
\hline pH & $\mathrm{pH}$ units & $8 \pm 0.1$ \\
Turbidity & $\mathrm{NTU}$ & $20 \pm 0.8$ \\
Temperature & ${ }^{\circ}$ & $24 \pm 0.5$ \\
Biochemical oxygen demand (BOD 5$)$ & $\mathrm{mg} / \mathrm{L}$ & $25.3 \pm 0.02$ \\
Chemical oxygen demand (COD) & $\mathrm{mg} / \mathrm{L}$ & $41 \pm 0.05$ \\
Total alkalinity & $\mathrm{mg} / \mathrm{L} \mathrm{CaCO}$ & $80.88 \pm 4.2$ \\
Acidity & $\mathrm{mg} / \mathrm{L} \mathrm{CaCO}_{3}$ & $6 \pm 0.08$ \\
Total hardness & $\mathrm{mg} / \mathrm{L} \mathrm{CaCO}_{3}$ & $90 \pm 0.82$ \\
Calcium hardness & $\mathrm{mg} / \mathrm{L} \mathrm{CaCO}_{3}$ & $62.5 \pm 0.3$ \\
Nitrates & $\mathrm{mg} / \mathrm{L} \mathrm{NO}_{3}$ & $80 \pm 0.04$ \\
Phosphates & $\mathrm{mg} / \mathrm{L} \mathrm{PO}_{4}$ & $70 \pm 0.07$ \\
\hline
\end{tabular}

\subsection{Effect of Carbon Source}

According to the results, higher concentrations of sodium carbonate and sodium bicarbonate $(>1 \mathrm{~g} / \mathrm{L})$ improved the final concentration of biomass in both strains in comparison with the strain's growth either in Bold Basal Medium (Control BBM) or in wastewater (control WW). Between both strains, Chlorella sp. grew slightly better in the wastewater (up to $0.51 \mathrm{~g} / \mathrm{L}$ ) than Scenedesmus sp. $(0.41 \mathrm{~g} / \mathrm{L})$ supplemented with the different carbon 
sources; however, sodium bicarbonate enhanced the production of biomass (Figure 2a) and protein (Figure $2 b$ ) compared to sodium carbonate.
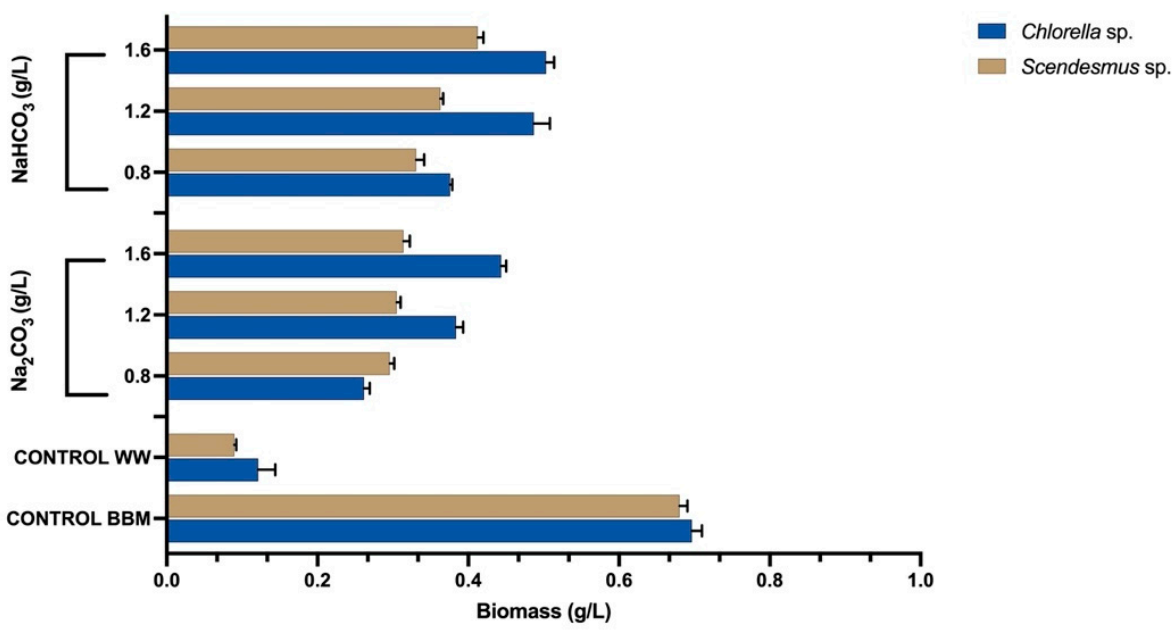

(a)

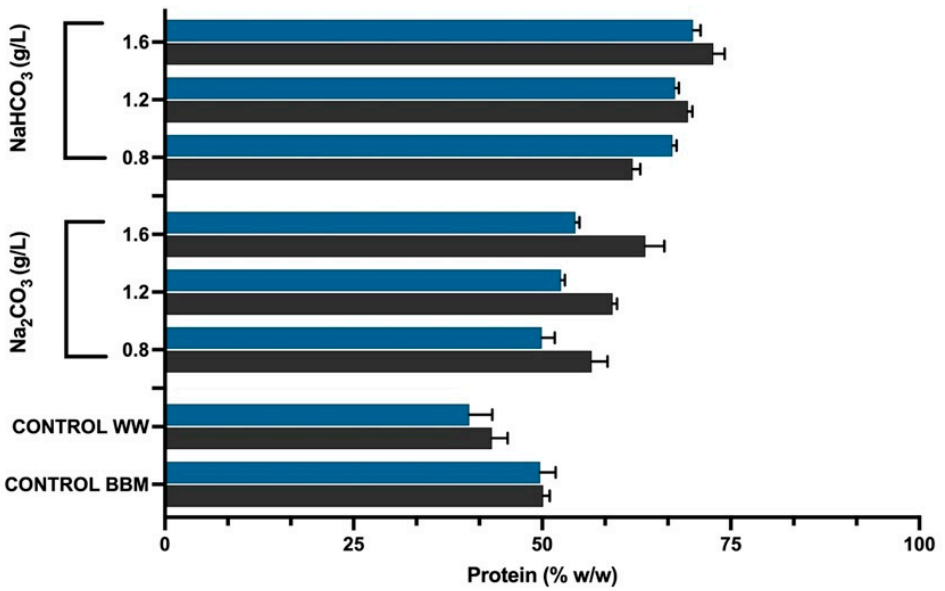

Chlorella sp.

Scendesmus sp.

(b)

Figure 2. Biomass concentration (a) and protein content (b) using different sodium carbonate and sodium bicarbonate concentrations.

Unlike biomass, $\mathrm{NO}_{3}$ and $\mathrm{PO}_{4}$ removal from both strains remained relatively constant, even compared to the two controls (BBM and WW). According to the results for $\mathrm{NO}_{3}$ uptake (Figure 3a), there was no significant difference between both carbon sources and controls. On the other hand, the removal of $\mathrm{PO}_{4}$ (Figure 3b) seemed to be influenced by carbon source concentration. In the experiments with higher $\mathrm{Na}_{2} \mathrm{CO}_{3}$ and $\mathrm{NaHCO}_{3}$, over $80 \%$ of $\mathrm{PO}_{4}$ was consumed. 


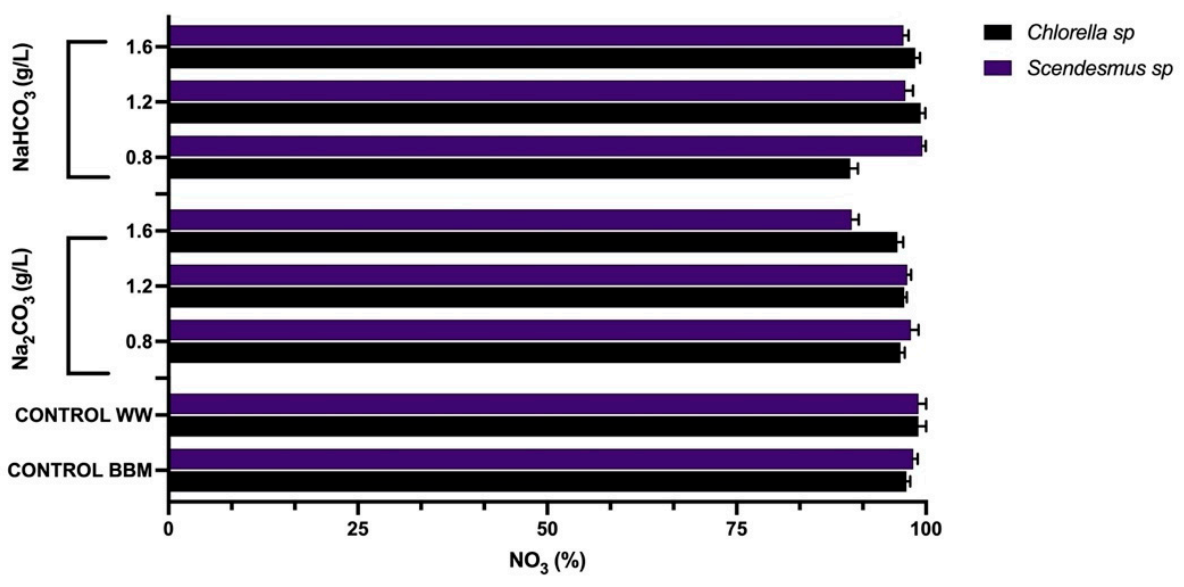

(a)

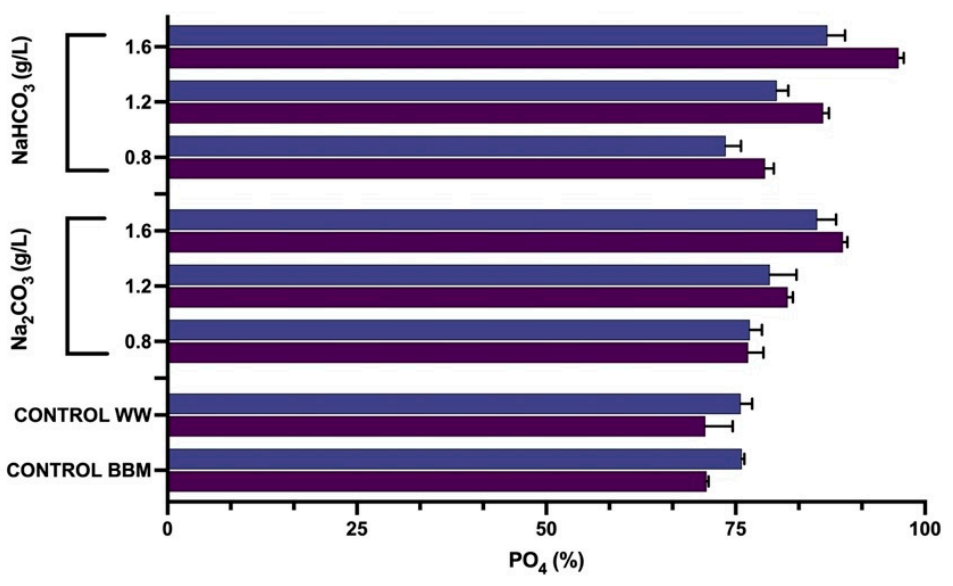

Chlorella sp

Scendesmus sp

(b)

Figure 3. Nitrate $\left(\mathrm{NO}_{3}\right)(\mathbf{a})$ and phosphate $\left(\mathrm{PO}_{4}\right)$ removal $(\mathbf{b})$ using different concentrations of sodium carbonate and sodium bicarbonate.

\subsection{Supplemented Wastewater}

The effect of supplementing the wastewater with $\mathrm{N}, \mathrm{P}$, and a carbon source was analyzed. To achieve this, the concentrations of $\mathrm{NaNO}_{3}$, phosphate buffer $\left(\mathrm{K}_{2} \mathrm{HPO}_{4}\right.$ and $\left.\mathrm{KH}_{2} \mathrm{PO}_{4}\right)$ present in the Bold Basal Medium [48], and sodium bicarbonate $\left(\mathrm{NaHCO}_{3}\right)$ as the carbon source were used. These components' effect was evaluated using a nonfactorial response surface design with three factors, three levels, and two central points. The resolved design can be found in Table 2.

The experimental data concerning the effects of the concentration of $\mathrm{NaNO}_{3}, \mathrm{NaHCO}_{3}$, and phosphate buffer $\left(\mathrm{K}_{2} \mathrm{HPO}_{4}\right.$ and $\left.\mathrm{KH}_{2} \mathrm{PO}_{4}\right)$ on the production of biomass were fitted on two models: linear (L) and quadratic (Q) (Figure $4 \mathrm{~b}, \mathrm{~d}$ ). $\mathrm{NaHCO}_{3}$ and phosphate buffer affected the final biomass concentration on both strains. Figure $4 \mathrm{a}, \mathrm{c}$ presents the response surface plots for the effect of $\mathrm{NaHCO}_{3} / \mathrm{K}_{2} \mathrm{HPO}_{4}+\mathrm{KH}_{2} \mathrm{PO}_{4}$ in the concentration of biomass for Chlorella sp. and Scenedesmus sp. According to the results, relatively more significant concentrations of buffer phosphate $(>10 \mathrm{~mL} / \mathrm{L})$ and low concentrations of $\mathrm{NaHCO}_{3}(0.4-0.8 \mathrm{~g} / \mathrm{L})$ substantially increased the final concentration of biomass in Chlorella sp. On the other hand, relatively higher concentrations of buffer phosphate $(>10 \mathrm{~mL} / \mathrm{L})$ and $\mathrm{NaHCO}_{3}(>1.5 \mathrm{~g} / \mathrm{L})$ substantially increased the final concentration of biomass in Scenedesmus sp. 
Table 2. Design of experiments for $\mathrm{C} / \mathrm{N} / \mathrm{P}$ ratio analysis.

\begin{tabular}{ccccc}
\hline \multirow{2}{*}{ Experiment } & \multirow{N}{*}{$\mathbf{N a N O}_{3}(\mathbf{m L} / \mathbf{L})$} & \multicolumn{2}{c}{ Phosphate Buffer } & \\
\cline { 3 - 4 } & & $\mathbf{K}_{\mathbf{2}} \mathbf{H P O}_{\mathbf{4}}(\mathbf{m L} / \mathbf{L})$ & $\mathbf{K H}_{\mathbf{2}} \mathbf{P O}_{\mathbf{4}}(\mathbf{m L} / \mathbf{L})$ & \\
\hline $10(\mathrm{C})$ & 7 & 7 & 7 & 1.2 \\
12 & 10.3 & 7 & 7 & 1.2 \\
$17(\mathrm{C})$ & 7 & 7 & 7 & 1.2 \\
13 & 7 & 3,7 & 3,7 & 1.2 \\
6 & 5 & 5 & 5 & 1.6 \\
11 & 3.7 & 7 & 7 & 1.2 \\
14 & 7 & 10.3 & 10.3 & 1.2 \\
2 & 5 & 9 & 9 & 1.6 \\
3 & 9 & 5 & 5 & 1.6 \\
9 & 9 & 9 & 9 & 1.6 \\
1 & 5 & 5 & 5 & 0.8 \\
4 & 9 & 9 & 9 & 0.8 \\
7 & 5 & 9 & 9 & 0.8 \\
$5(\mathrm{C})$ & 7 & 7 & 7 & 1.2 \\
16 & 7 & 7 & 7 & 0.8 \\
8 & 9 & 5 & 5 & 0.53 \\
15 & 7 & 7 & 7 & \\
\hline
\end{tabular}

Fitted Surface; Variable: Chlorella_Biomass ( $g / \mathrm{L}$ )

S Residual $=002745$

DV: Chlorella_Biomass ( $\mathrm{g} / \mathrm{L}$ )

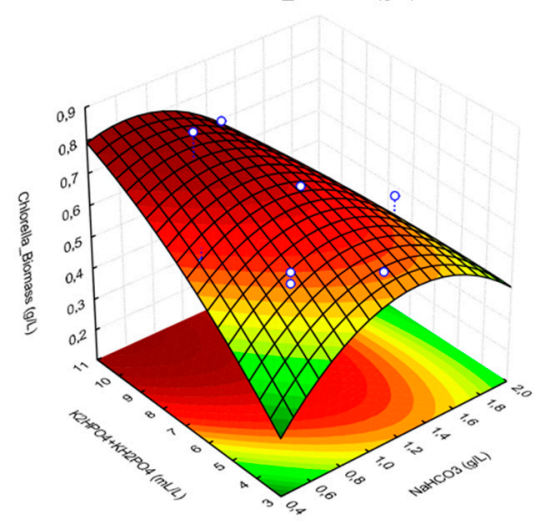

(a)

Fitted Surface; Variable: Scenedesmus_Biomass (g/L) 3 factors, 1 Blocks, 17 Runs; MS Residual=, 0034448 DV: Scenedesmus_Biomass $(\mathrm{g} / \mathrm{L})$

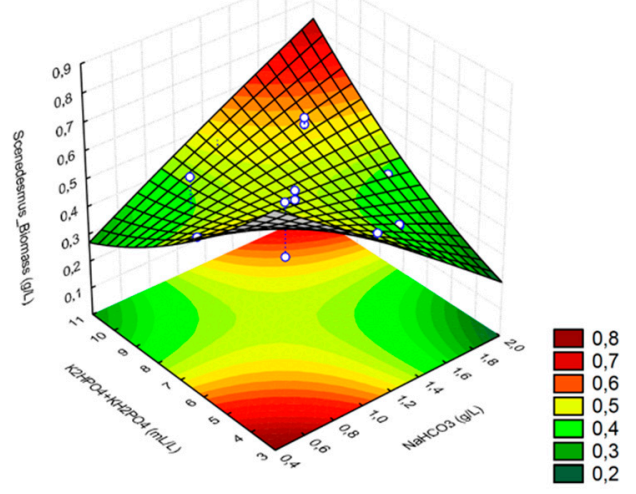

(c)

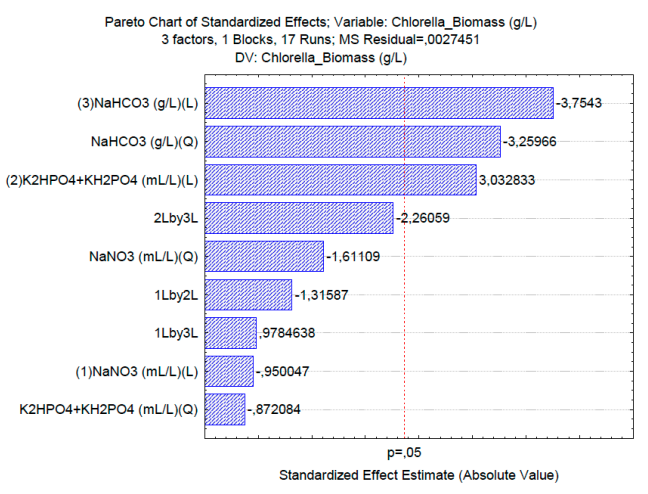

(b)

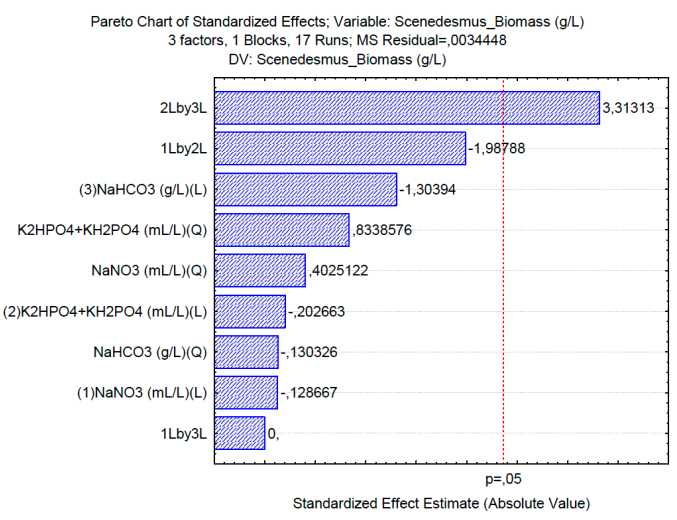

(d)

Figure 4. Surface response and Pareto charts for Chlorella sp. (a,b), and Scenedesmus sp. (c,d). 
By analyzing the results from the interactions found between the variables (Figure $4 \mathrm{a}-\mathrm{d}$ ), the ratio $\mathrm{NaHCO}_{3}$ to $\mathrm{KH}_{2} \mathrm{PO}_{4}+\mathrm{K}_{2} \mathrm{HPO}_{4}$ was chosen. Table 3 represents the highest scenarios for biomass concentration; $X$ is the concentration of $\mathrm{NaHCO}_{3}(\mathrm{~mL} / \mathrm{L})$, and $\mathrm{Y}$ is the concentration of $\mathrm{KH}_{2} \mathrm{PO}_{4}+\mathrm{K}_{2} \mathrm{HPO}_{4}(\mathrm{~mL} / \mathrm{L})$ while maintaining $\mathrm{NaNO}_{3}$ at $5 \mathrm{~mL} / \mathrm{L}\left(0.125 \mathrm{~g} / \mathrm{L}\right.$ of $\left.\mathrm{NaNO}_{3}\right)$ for each strain. The production of biomass on Chlorella sp. and Scenedesmus sp. was further tested on a $50 \mathrm{~L}$ flat-plate PBR $\left(0.78 \mathrm{~L} \cdot \mathrm{min}^{-1}\right.$ of filtered air, $12: 12 \mathrm{~h}$ light/dark cycle at $100 \mu \mathrm{mol} \cdot \mathrm{m}^{-2} \cdot \mathrm{s}^{-1}$ for 30 days) using supplemented wastewater with the optimal conditions for carbon and phosphate source while maintaining $\mathrm{NaNO}_{3}$ at $5 \mathrm{~mL} / \mathrm{L}$.

Table 3. Variables for optimal biomass concentration on both strains were studied.

\begin{tabular}{|c|c|c|c|}
\hline Strain & Label & Variable & Value \\
\hline \multirow{3}{*}{ Chlorella sp. } & $X$ & $\mathrm{NaHCO}_{3}(\mathrm{~g} / \mathrm{L})$ & 0.5 \\
\hline & $\mathrm{Y}$ & $\mathrm{KH}_{2} \mathrm{PO}_{4}+\mathrm{K}_{2} \mathrm{HPO}_{4}(\mathrm{~mL} / \mathrm{L})$ & 11 \\
\hline & $Z_{\text {(expected) }}$ & Biomass $(\mathrm{g} / \mathrm{L})$ & 0.87 \\
\hline \multirow{3}{*}{ Scenedesmus sp. } & $X$ & $\mathrm{NaHCO}_{3}(\mathrm{~g} / \mathrm{L})$ & 2 \\
\hline & $\mathrm{Y}$ & $\mathrm{KH}_{2} \mathrm{PO}_{4}+\mathrm{K}_{2} \mathrm{HPO}_{4}(\mathrm{~mL} / \mathrm{L})$ & 11 \\
\hline & $Z_{(\text {expected) }}$ & Biomass $(\mathrm{g} / \mathrm{L})$ & 0.83 \\
\hline
\end{tabular}

Under the optimized conditions, the concentration of biomass produced was slightly higher than the expected result for Chlorella sp. and Scenedesmus sp. (0.9 and $0.87 \mathrm{~g} / \mathrm{L})$ (Figure 5a), with an interesting concentration of carbohydrates $(22.5 \%$ and $23.5 \% w / w)$, proteins $(45.8 \%$ and $42.8 \% w / w)$, lipids (13.6 and $12.2 \% w / w)$, total carotenoids $(1.6 \%$ and $2.5 \% w / w)$, and ash $(15.4 \%$ and $15.3 \% w / w)$ (Figure $5 \mathrm{~b})$. The removal of $\mathrm{NO}_{3}$ and $\mathrm{PO}_{4}$ (Figure $5 \mathrm{c}$ ) showed that over $95 \%$ of the available $\mathrm{NO}_{3}$ and up to $50 \%$ of $\mathrm{PO}_{4}$ were consumed by both strains.

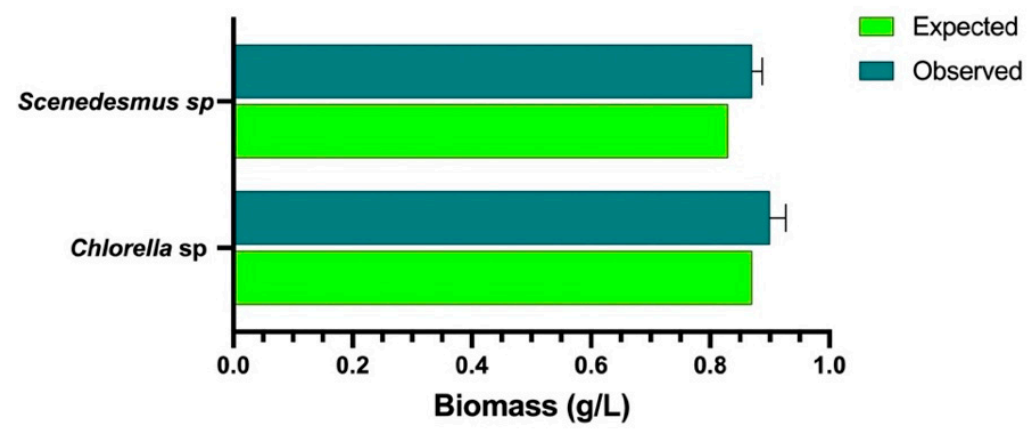

(a)

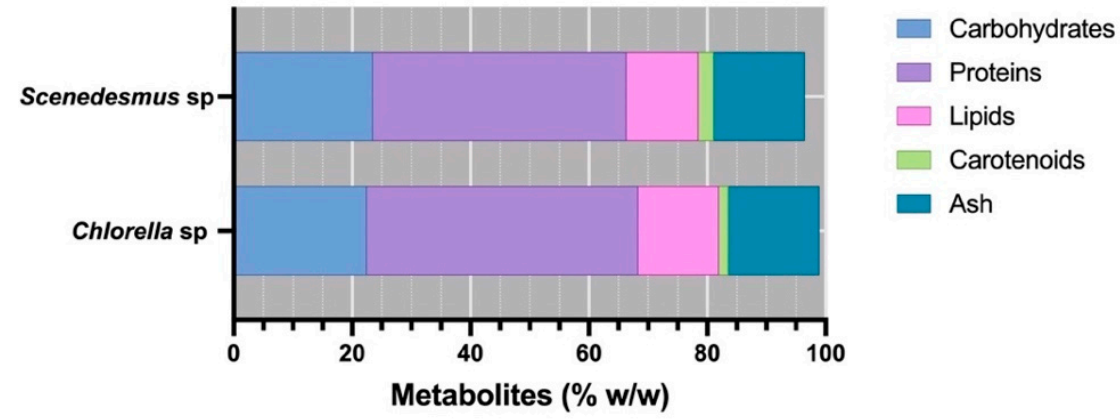

(b)

Figure 5. Cont. 


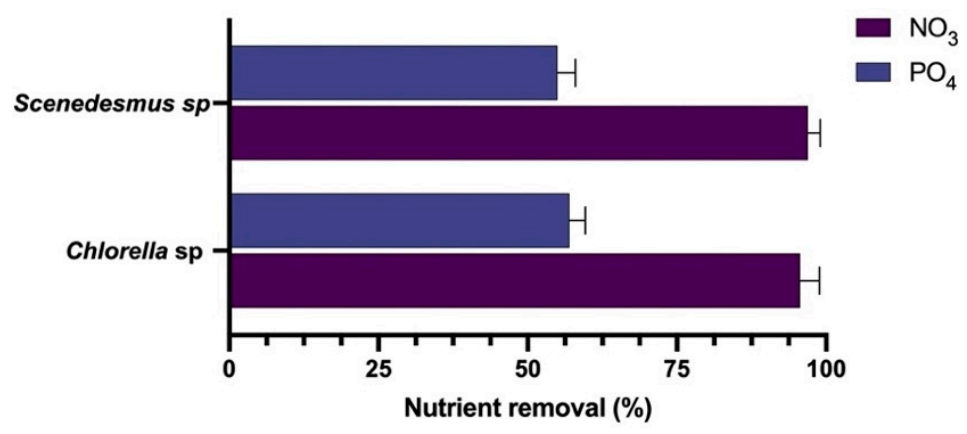

(c)

Figure 5. Biomass production (a), its composition (b), and nutrient removal (c) under the optimized conditions for the supplemented wastewater for Chlorella sp. and Scenedesmus sp.

\section{Discussion}

\subsection{Effect of Carbon Source}

The analysis and selection of the carbon source are critical steps in the production of algal and cyanobacterial biomass; the correct concentration of the carbon source employed will enhance the synthesis and accumulation of the metabolites of interest [58]. Most of the studies found in the literature used $\mathrm{CO}_{2}$ as the primary carbon source; however, sodium carbonate is the preferred carbon source on different culture media such as BG11. Other carbon sources such as sodium bicarbonate and sodium acetate have been studied as an alternative source for algal production. Lu et al. [59] found that sodium bicarbonate significantly reduced the content of $\mathrm{N}$ and $\mathrm{P}$ while producing up to $1.7 \mathrm{~g} / \mathrm{L}$ of Spirulina platensis in raw swine wastewater. In our case, both strains grew better on the wastewater supplemented with up to $1.6 \mathrm{~g} / \mathrm{L}$ of sodium bicarbonate; however, the final biomass concentration was relatively low $(0.4-0.6 \mathrm{~g} / \mathrm{L})$ for both strains, which may have been due to lower levels of $\mathrm{N}$ and $\mathrm{P}$ available. In another study, Do et al. [60] tested the efficiency of a new strain of Scenedesmus acuminatus in high carbonate levels. The authors found that the strain was able to withstand up to $4.2 \mathrm{~g} / \mathrm{L}$ of sodium bicarbonate with an exciting concentration of biomass $(1.7 \mathrm{~g} / \mathrm{L})$ and high removal of $\mathrm{N}$ and P. Other works using sodium carbonate [61] and sodium bicarbonate [62] on S. obliquus found lower biomass concentration values (0.21 and $0.68 \mathrm{~g} / \mathrm{L}$ respectively). Lastly, Barajas-Solano et al. [63] found that a relatively low concentration of sodium carbonate enhanced the biomass and hydrocarbon production on a Colombian strain of Botryococcus braunni.

\subsection{Supplemented Wastewater}

In the region of Norte de Santander (Colombia), most of the inland fisheries work under a constant exchange of water; this process allows the removal of high nutrient content from the production systems while maintaining oxygen levels, which helps the fish to grow and prevents the proliferation of blooms of toxic microorganisms. The latter explains the lower $\mathrm{NO}_{3}$ and $\mathrm{PO}_{4}$ found in the samples. Therefore, the wastewater must be supplemented with an external source of $\mathrm{N}$ and $\mathrm{P}$ to support the microalgal growth to produce fish feed, which may increase the cost of production. According to early results from our research group, an algal production plant of $500 \mathrm{~m}^{3}$ using fishery wastewater supplemented with $\mathrm{N}$ and $\mathrm{P}$ can produce up to $11,875 \mathrm{~kg} /$ year $(31.3 \mathrm{~kg} /$ day $)$ with a production cost of up to $18 \mathrm{USD} / \mathrm{kg}$ for dry biomass (dry feed) and $0.19 \mathrm{USD} /$ bottle for concentrated liquid biomass (live feed) [64].

In the present study, we sought to determine the concentration of $\mathrm{N}, \mathrm{P}$, and carbon that favored biomass production using a nonfactorial response surface design, an interesting tool for optimizing different processes, including algal production [65]. Our results show that the interaction between sodium bicarbonate and the phosphate source improved biomass production; to the best of our knowledge, this is the first report on the effect of P/C interaction on biomass concentration using wastewater from inland fisheries. Most of the 
works published in the last few years focused on the viability of $\mathrm{N}, \mathrm{P}$, and the carbon source concentration (in the form of $\mathrm{CO}_{2}$ ). Nitrogen and phosphate are destined to synthesize proteins and essential metabolites, while carbon is employed on nitrogen fixation and biomass production [63].

The application of microalgal cultures as a sustainable process for the removal of nutrients has been studied on wastewater from Oreochromis niloticus [3,20,22,24-26,38], Lates calcarifer [8], shrimp culture [29-31], Mugil cephalus [10,32], Sparus aurata [10,16], Scophthalmus maximus [39], and even synthetic wastewater [32,36]. According to the results, the percentage of $\mathrm{NO}_{3}$ removed $(>95 \%)$ is similar to that reported by most authors; however, the rate of $\mathrm{PO}_{4}$ was lower than other authors since the wastewater was supplemented with external $P$.

The concentration of biomass produced is affected not only by the biological behavior of the strain but also by the source of the wastewater and the method in which the algae is grown. In general, the biomass concentration reported for different strains in a wide range of aquacultural wastewater ranges between 0.1 to $1 \mathrm{~g} / \mathrm{L}$. The highest recorded concentrations of algal biomass were reported by Han et al. [40], Guldhe et al. [22], and Tejido-Nuñez et al. [3] (2.52, 2.47, and $2.28 \mathrm{~g} / \mathrm{L}$, respectively); however, Han et al. used algae-bacteria consortia, while Gulde et al. grew the strain in heterotrophic mode, and Tejido-Nuñez et al. used non-sterile wastewater. Some other authors such as Malibari et al. [23] and Ge et al. [29] reported the lowest biomass concentration $(<0.5 \mathrm{~g} / \mathrm{L})$; even when the authors evaluated a wide range of algal strains, the wastewater evaluated was obtained from shrimp culture (including Penaeus (Litopenaeu) vannamei). Therefore, this type of wastewater does not possess high nutrients for algal production. The different studies listed in Table 4 show similar levels of $\mathrm{NO}_{3}$ and $\mathrm{PO}_{4}$ removal, which implies that the different strains studied are capable of consuming those nutrients; however, unless the wastewater comes from recirculating aquaculture systems (RASs), such as the work of Dourou et al. [10], is supplemented with pulp wastewater [34], is enriched with biogas digestate [41], or is even enriched with a culture medium [37], this type of wastewater is not able to sustain large concentrations of algal biomass. Lastly, the protein content in those strains ranges between $24 \%$ and $60 \%(w / w)$, which makes them an exciting source for fish feed. 
Table 4. Strains evaluated for removing nutrients $\left(\mathrm{NO}_{3}\right.$ and $\left.\mathrm{PO}_{4}\right)$ and the concentration of biomass produced in different aquacultural wastewater.

\begin{tabular}{|c|c|c|c|c|c|c|}
\hline Strain & $\begin{array}{c}\text { Biomass Yield } \\
(\mathrm{g} / \mathrm{L})\end{array}$ & $\begin{array}{l}\text { Protein Content } \\
(\% w / w)\end{array}$ & Source of Wastewater & $\begin{array}{c}\mathrm{NO}_{3} \text { Removal } \\
(\%)\end{array}$ & $\begin{array}{c}\mathrm{PO}_{4} \text { Removal } \\
(\%)\end{array}$ & Reference \\
\hline Chlamydomonas sp. & 0.66 & $\mathrm{n} / \mathrm{a}$ & Oreochromis niloticus & 84.7 & 96 & [21] \\
\hline \multirow{2}{*}{ Chlorella sp. } & 0.058 & $\mathrm{n} / \mathrm{a}$ & Shrimp culture & $>90$ & $>90$ & [23] \\
\hline & $\mathrm{n} / \mathrm{a}$ & $\mathrm{n} / \mathrm{a}$ & Lates calcarifer & - & 99 & {$[8]$} \\
\hline $\begin{array}{l}\text { Chlorella sp. } \\
\text { NIVA CHL-137 }\end{array}$ & 0.39 & $\mathrm{n} / \mathrm{a}$ & \multirow[t]{2}{*}{ O. niloticus } & 98.1 & $\mathrm{n} / \mathrm{a}$ & [24] \\
\hline C. sorokiniana & $2.47^{1}$ & 24.57 & & 84.51 & 73.35 & [22] \\
\hline $\begin{array}{l}\text { C. sorokiniana } \\
211 / 8 \mathrm{~K}\end{array}$ & 0.476 & $\mathrm{n} / \mathrm{a}$ & \multirow[t]{3}{*}{ O. niloticus } & 78 & 77 & [25] \\
\hline \multirow{6}{*}{ C. vulgaris } & 1.1 & $\mathrm{n} / \mathrm{a}$ & & 94.6 & 97.9 & [21] \\
\hline & 0.58 & $\mathrm{n} / \mathrm{a}$ & & 95 & 81 & [26] \\
\hline & 2.85 & 57 & catfish & $\mathrm{n} / \mathrm{a}$ & $\mathrm{n} / \mathrm{a}$ & [27] \\
\hline & $\mathrm{n} / \mathrm{a}$ & $\mathrm{n} / \mathrm{a}$ & $\begin{array}{l}\text { carps, trout, and } \\
\text { sturgeon larvae }\end{array}$ & 92.23 & 89.25 & [28] \\
\hline & 0.426 & $\mathrm{n} / \mathrm{a}$ & \multirow{2}{*}{ Shrimp culture } & 86.1 & 82.7 & [29] \\
\hline & $\mathrm{n} / \mathrm{a}$ & $\mathrm{n} / \mathrm{a}$ & & 99 & $\mathrm{n} / \mathrm{a}$ & [30] \\
\hline C. vulgaris LH-1 & 1.1 & $\mathrm{n} / \mathrm{a}$ & \multirow{2}{*}{$\begin{array}{c}\text { Marine aquaculture } \\
\text { synthetic intensive } \\
\text { aquaculture }\end{array}$} & 97.3 & 53.8 & {$[31]$} \\
\hline C. vulgaris 2714 & $1.12^{2}$ & $\mathrm{n} / \mathrm{a}$ & & 99 & 95 & [32] \\
\hline $\begin{array}{l}\text { C. vulgaris } \\
\text { CCAP } 211 / 11 B\end{array}$ & $1.31^{3}$ & 49.96 & $\begin{array}{l}\text { closed recirculating } \\
\text { aquaculture system }\end{array}$ & 76.56 & 92.72 & [34] \\
\hline $\begin{array}{c}\text { C. vulgaris } \\
\text { CCAP 211/52 }\end{array}$ & 2.28 & $\mathrm{n} / \mathrm{a}$ & O. niloticus & 99.8 & 99.7 & [3] \\
\hline Dunaliella sp. & 0.061 & $\mathrm{n} / \mathrm{a}$ & Shrimp culture & $>90$ & $>90$ & [23] \\
\hline \multirow[b]{2}{*}{ D. tertiolecta } & 0.38 & $\mathrm{n} / \mathrm{a}$ & \multirow{3}{*}{ Mugil Cephalus } & 95.44 & 91.19 & [33] \\
\hline & 0.329 & $\mathrm{n} / \mathrm{a}$ & & 96 & 99 & [32] \\
\hline Isochrysis galbana & 0.16 & $\mathrm{n} / \mathrm{a}$ & & 66.02 & 91.93 & [33] \\
\hline Nannochloropsis sp. & 0.073 & $\mathrm{n} / \mathrm{a}$ & $\begin{array}{l}\text { Shrimp culture } \\
\text { Sparus aurata and }\end{array}$ & $>90$ & $>90$ & [23] \\
\hline N. gaditana & 0.847 & 41 & $\begin{array}{l}\text { Dicentrarchus labrax } \\
\text { production }\end{array}$ & 92 & 87 & [10] \\
\hline Navicula sp. 1 & 0.083 & $\mathrm{n} / \mathrm{a}$ & \multirow{2}{*}{ Shrimp culture } & $>90$ & $>90$ & \multirow{2}{*}{ [23] } \\
\hline Navicula sp. 2 & 0.077 & $\mathrm{n} / \mathrm{a}$ & & $>90$ & $>90$ & \\
\hline
\end{tabular}


Table 4. Cont.

\begin{tabular}{|c|c|c|c|c|c|c|}
\hline Strain & $\begin{array}{l}\text { Biomass Yield } \\
(\mathrm{g} / \mathrm{L})\end{array}$ & $\begin{array}{l}\text { Protein Content } \\
\quad(\% w / w)\end{array}$ & Source of Wastewater & $\begin{array}{c}\mathrm{NO}_{3} \text { Removal } \\
(\%)\end{array}$ & $\mathrm{PO}_{4} \underset{(\%)}{\text { Removal }}$ & Reference \\
\hline Oscillatoria okeni & 0.38 & $\mathrm{n} / \mathrm{a}$ & O. niloticus & 90 & 75 & [26] \\
\hline Parachlorella kessleri TY & 0.275 & $\mathrm{n} / \mathrm{a}$ & Aquaculture wastewater & 99 & 95.6 & [35] \\
\hline Platymonas helgolandica & $\mathrm{n} / \mathrm{a}$ & $\mathrm{n} / \mathrm{a}$ & \multirow{2}{*}{ Shrimp culture } & 99 & $\mathrm{n} / \mathrm{a}$ & {$[31]$} \\
\hline Scenedesmus obliquus & 0.07 & $\mathrm{n} / \mathrm{a}$ & & 85 & 79 & [32] \\
\hline $\begin{array}{l}\text { Sc. quadricauda } \\
\text { NIVA-CHL } 7\end{array}$ & 0.38 & $\mathrm{n} / \mathrm{a}$ & \multirow[t]{2}{*}{ O. niloticus } & 98.7 & $\mathrm{n} / \mathrm{a}$ & {$[24]$} \\
\hline Spirulina sp. & $1.1^{4}$ & 65.73 & & 72.11 & 93.84 & [37] \\
\hline $\begin{array}{l}\text { Synedra sp. } \\
\text { FACHB-1712 }\end{array}$ & $0.37^{5}$ & $\mathrm{n} / \mathrm{a}$ & $\begin{array}{c}\text { Freshwater aquaculture } \\
\text { pond }\end{array}$ & 65.44 & 68.98 & [38] \\
\hline $\begin{array}{l}\text { Tetradesmus obliquus } \\
\text { SAG 276-1 }\end{array}$ & 1.98 & $\mathrm{n} / \mathrm{a}$ & O. niloticus & 99.7 & 99.6 & [3] \\
\hline Tetraselmis sp. & 0.081 & $\mathrm{n} / \mathrm{a}$ & Shrimp culture & $>90$ & $>90$ & [23] \\
\hline T. chuii & 1.38 & 39.8 & Sea bass & 99 & $\mathrm{n} / \mathrm{a}$ & [15] \\
\hline \multirow{2}{*}{ T. suecica } & 1.97 & 50.2 & Sparus aurata & 99.8 & 98.7 & [16] \\
\hline & 1.0 & $\mathrm{n} / \mathrm{a}$ & Scophthalmus maximus & 95.7 & 99 & [39] \\
\hline Algal-bacterial biofilm & 2.52 & $\mathrm{n} / \mathrm{a}$ & $\begin{array}{l}\text { Fish and shrimp } \\
\text { mixed culture }\end{array}$ & 95 & 99 & [40] \\
\hline Mixed consortia & $1.99^{6}$ & $\mathrm{n} / \mathrm{a}$ & Aquaculture effluent & 99.5 & 99.2 & [41] \\
\hline Chlorella sp. & 0.9 & 45.8 & Inland fish production & & 52.3 & \\
\hline Scenedesmus sp. & 0.87 & 42.8 & (Oreochromis sp.) & $>95$ & 51.4 & This study \\
\hline
\end{tabular}

${ }^{1}$ Growth under heterotrophic conditions. ${ }^{2}$ Co-cultivated with Mucor indicus $24905 .{ }^{3}$ Mixture of pulp $(60 \%)$ and aquaculture $(40 \%)$ wastewater. ${ }^{4}$ Wastewater supplemented with $25 \%(v / v)$ of Zarrouk medium. ${ }^{5} \mathrm{~N}: \mathrm{P}$ ratio adjusted to $6: 1 .{ }^{6}$ Enriched with biogas digestate. 


\section{Conclusions}

In this study, we found that wastewater from inland fisheries dedicated to the production of Oreochromis sp. must be supplemented with an external source of $\mathrm{N}$ and $\mathrm{P}$ to work as a nutrient source for algal biomass production. Results from the optimization using nonfactorial response surface design show that the addition of $\mathrm{NaNO}_{3}(0.125 \mathrm{~g} / \mathrm{L})$, $\mathrm{K}_{2} \mathrm{HPO}_{4}(0.075 \mathrm{~g} / \mathrm{L}), \mathrm{KH}_{2} \mathrm{PO}_{4}(0.75 \mathrm{~g} / \mathrm{L})$, and $\mathrm{NaHCO}_{3}(0.5$ and $2 \mathrm{~g} / \mathrm{L}$ for Chlorella sp. and Scenedesmus sp. respectively) significantly increased the biomass of Chlorella sp. $(0.87 \mathrm{~g} / \mathrm{L})$ and Scenedesmus sp. $(0.83 \mathrm{~g} / \mathrm{L})$, where the $\mathrm{PO}_{4} / \mathrm{NaHCO}_{3}$ ratio increased the overall biomass production in both Chlorella sp. and Scenedesmus sp. Although these results show that the addition of other nutrients is not necessary, it is still critical to determine the quality of the biomass produced in terms of its application as a feed supplement for aquaculture production and the possible environmental impacts (positive or negative) generated by this type of process.

Author Contributions: Conceptualization, J.B.G.-M. and V.K.; methodology, A.F.B.-S. and C.B.-F.; software, A.F.B.-S.; validation, L.P.S.-T. and N.A.C.-A.; formal analysis, A.Z.; investigation, L.P.S.-T. and N.A.C.-A.; resources, A.F.B.-S. and C.B.-F.; data curation, A.Z.; writing-original draft preparation, J.B.G.-M.; writing-review and editing, A.F.B.-S. and A.Z.; visualization, C.B.-F.; supervision, V.K.; project administration, A.F.B.-S. and C.B.-F.; funding acquisition, A.F.B.-S. and C.B.-F. All authors have read and agreed to the published version of the manuscript.

Funding: This paper was partially supported by grants from Universidad Industrial de Santander (Colombia) and Newton-Caldas Fund Institutional Links, with the project "ALGALCOLOR: BioPlatform for the Sustainable Production of Cyanobacterial-Based Colors and Fine Chemicals" ID 527624805.

Institutional Review Board Statement: Not applicable.

Informed Consent Statement: Not applicable.

Data Availability Statement: Not applicable.

Acknowledgments: We would like to express our sincere gratitude to Universidad Francisco de Paula Santander (Colombia), Universidad Industrial de Santander and Sapienza University of Rome for providing the equipment for this research and the Colombian Ministry of Science Technology and Innovation MINCIENCIAS for supporting national Ph.D. doctorates through the Francisco José de Caldas scholarship program.

Conflicts of Interest: The authors declare no conflict of interest.

\section{References}

1. FAO. The State of World Fisheries and Aquaculture 2020. Sustainability in Action; FAO: Rome, Italy, 2020; pp. 5-10. [CrossRef]

2. Crona, B.I.; Basurto, X.; Squires, D.; Gelcich, S.; Daw, T.M.; Khan, A.; Havice, E.; Chomo, V.; Troell, M.; Buchary, E.A.; et al. Towards a Typology of Interactions between Small-Scale Fisheries and Global Seafood Trade. Mar. Policy 2016, 65, 1-10. [CrossRef]

3. Tejido-Nuñez, Y.; Aymerich, E.; Sancho, L.; Refardt, D. Treatment of Aquaculture Effluent with Chlorella Vulgaris and Tetradesmus Obliquus: The Effect of Pretreatment on Microalgae Growth and Nutrient Removal Efficiency. Ecol. Eng. 2019, 136, 1-9. [CrossRef]

4. Lynch, A.J.; Cowx, I.G.; Fluet-Chouinard, E.; Glaser, S.M.; Phang, S.C.; Beard, T.D.; Bower, S.D.; Brooks, J.L.; Bunnell, D.B.; Claussen, J.E.; et al. Inland Fisheries-Invisible but Integral to the UN Sustainable Development Agenda for Ending Poverty by 2030. Glob. Environ. Chang. 2017, 47, 167-173. [CrossRef]

5. Van Den Hende, S.; Beelen, V.; Bore, G.; Boon, N.; Vervaeren, H. Up-Scaling Aquaculture Wastewater Treatment by Microalgal Bacterial Flocs: From Lab Reactors to an Outdoor Raceway Pond. Bioresour. Technol. 2014, 159, 342-354. [CrossRef]

6. Mook, W.T.; Chakrabarti, M.H.; Aroua, M.K.; Khan, G.M.A.; Ali, B.S.; Islam, M.S.; Abu Hassan, M.A. Removal of Total Ammonia Nitrogen (TAN), Nitrate and Total Organic Carbon (TOC) from Aquaculture Wastewater Using Electrochemical Technology: A Review. Desalination 2012, 285, 1-13. [CrossRef]

7. Chen, S.; Yu, J.; Wang, H.; Yu, H.; Quan, X. A Pilot-Scale Coupling Catalytic Ozonation-Membrane Filtration System for Recirculating Aquaculture Wastewater Treatment. Desalination 2015, 363, 37-43. [CrossRef]

8. Crab, R.; Avnimelech, Y.; Defoirdt, T.; Bossier, P.; Verstraete, W. Nitrogen Removal Techniques in Aquaculture for a Sustainable Production. Aquaculture 2007, 270, 1-14. [CrossRef] 
9. Lananan, F.; Abdul Hamid, S.H.; Din, W.N.S.; Ali, N.; Khatoon, H.; Jusoh, A.; Endut, A. Symbiotic Bioremediation of Aquaculture Wastewater in Reducing Ammonia and Phosphorus Utilizing Effective Microorganism (EM-1) and Microalgae (Chlorella Sp.). Int. Biodeterior. Biodegrad. 2014, 95, 127-134. [CrossRef]

10. Dourou, M.; Tsolcha, O.N.; Tekerlekopoulou, A.G.; Bokas, D.; Aggelis, G. Fish Farm Effluents Are Suitable Growth Media for Nannochloropsis Gaditana, a Polyunsaturated Fatty Acid Producing Microalga. Eng. Life Sci. 2018, 18, 851-860. [CrossRef]

11. Nasir, N.M.; Bakar, N.S.A.; Lananan, F.; Abdul Hamid, S.H.; Lam, S.S.; Jusoh, A. Treatment of African Catfish, Clarias Gariepinus Wastewater Utilizing Phytoremediation of Microalgae, Chlorella Sp. with Aspergillus Niger Bio-Harvesting. Bioresour. Technol. 2015, 190, 492-498. [CrossRef] [PubMed]

12. Fernández-Arévalo, T.; Lizarralde, I.; Fdz-Polanco, F.; Pérez-Elvira, S.I.; Garrido, J.M.; Puig, S.; Poch, M.; Grau, P.; Ayesa, E. Quantitative Assessment of Energy and Resource Recovery in Wastewater Treatment Plants Based on Plant-Wide Simulations. Water Res. 2017, 118, 272-288. [CrossRef] [PubMed]

13. Spiliotopoulou, A.; Rojas-Tirado, P.; Chhetri, R.K.; Kaarsholm, K.M.S.; Martin, R.; Pedersen, P.B.; Pedersen, L.-F.; Andersen, H.R. Ozonation Control and Effects of Ozone on Water Quality in Recirculating Aquaculture Systems. Water Res. 2018, 133, 289-298. [CrossRef]

14. Quintero-Dallos, V.; García-Martínez, J.B.; Contreras-Ropero, J.E.; Barajas-Solano, A.F.; Barajas-Ferrerira, C.; Lavecchia, R.; Zuorro, A. Vinasse as a Sustainable Medium for the Production of Chlorella Vulgaris UTEX 1803. Water 2019, 11, 1526. [CrossRef]

15. Villar-Navarro, E.; Garrido-Pérez, C.; Perales, J.A. Recycling “Waste” Nutrients Back into RAS and FTS Marine Aquaculture Facilities from the Perspective of the Circular Economy. Sci. Total Environ. 2021, 762, 143057. [CrossRef] [PubMed]

16. Andreotti, V.; Solimeno, A.; Rossi, S.; Ficara, E.; Marazzi, F.; Mezzanotte, V.; García, J. Bioremediation of Aquaculture Wastewater with the Microalgae Tetraselmis Suecica: Semi-Continuous Experiments, Simulation, and Photo-Respirometric Tests. Sci. Total Environ. 2020, 738, 139859. [CrossRef] [PubMed]

17. Ebeling, J.M.; Sibrell, P.L.; Ogden, S.R.; Summerfelt, S.T. Evaluation of Chemical Coagulation-Flocculation Aids for the Removal of Suspended Solids and Phosphorus from Intensive Recirculating Aquaculture Effluent Discharge. Aquac. Eng. 2003, $29,23-42$. [CrossRef]

18. Gao, F.; Li, C.; Yang, Z.-H.; Zeng, G.-M.; Feng, L.-J.; Liu, J.; Liu, M.; Cai, H. Continuous Microalgae Cultivation in Aquaculture Wastewater by a Membrane Photobioreactor for Biomass Production and Nutrients Removal. Ecol. Eng. 2016, 92, 55-61. [CrossRef]

19. Hawrot-Paw, M.; Koniuszy, A.; Gałczynska, M.; Zajac, G.; Szyszlak-Bargłowicz, J. Production of Microalgal Biomass Using Aquaculture Wastewater as Growth Medium. Water 2020, 12, 106. [CrossRef]

20. Zuorro, A.; García-Martínez, J.B.; Barajas-Solano, A.F. The Application of Catalytic Processes on the Production of Algae-Based Biofuels: A Review. Catalysts 2021, 11, 22. [CrossRef]

21. Morando-Grijalva, C.A.; Vázquez-Larios, A.L.; Alcántara-Hernández, R.J.; Ortega-Clemente, L.A.; Robledo-Narváez, P.N. Isolation of a Freshwater Microalgae and Its Application for the Treatment of Wastewater and Obtaining Fatty Acids from Tilapia Cultivation. Environ. Sci. Pollut. Res. 2020, 27, 28575-28584. [CrossRef]

22. Guldhe, A.; Ansari, F.A.; Singh, P.; Bux, F. Heterotrophic Cultivation of Microalgae Using Aquaculture Wastewater: A Biorefinery Concept for Biomass Production and Nutrient Remediation. Ecol. Eng. 2017, 99, 47-53. [CrossRef]

23. Malibari, R.; Sayegh, F.; Elazzazy, A.M.; Baeshen, M.N.; Dourou, M.; Aggelis, G. Reuse of Shrimp Farm Wastewater as Growth Medium for Marine Microalgae Isolated from Red Sea-Jeddah. J. Clean. Prod. 2018, 198, 160-169. [CrossRef]

24. Halfhide, T.; Åkerstrøm, A.; Lekang, O.I.; Gislerød, H.R.; Ergas, S.J. Production of Algal Biomass, Chlorophyll, Starch and Lipids Using Aquaculture Wastewater under Axenic and Non-Axenic Conditions. Algal Res. 2014, 6, 152-159. [CrossRef]

25. Lugo, L.A.; Thorarinsdottir, R.I.; Bjornsson, S.; Palsson, O.P.; Skulason, H.; Johannsson, S.; Brynjolfsson, S. Remediation of Aquaculture Wastewater Using the Microalga Chlorella Sorokiniana. Water 2020, 12, 3144. [CrossRef]

26. Attasat, S.; Wanichpongpan, P.; Ruenglertpanyakul, W. Cultivation of Microalgae (Oscillatoria Okeni and Chlorella Vulgaris) Using Tilapia-Pond Effluent and a Comparison of Their Biomass Removal Efficiency. Water Sci. Technol. 2013, 67, 271-277. [CrossRef] [PubMed]

27. Mtaki, K.; Kyewalyanga, M.S.; Mtolera, M.S.P. Supplementing Wastewater with NPK Fertilizer as a Cheap Source of Nutrients in Cultivating Live Food (Chlorella Vulgaris). Ann. Microbiol. 2021, 71, 7. [CrossRef]

28. Hesni, M.A.; Hedayati, A.; Qadermarzi, A.; Pouladi, M.; Zangiabadi, S.; Naqshbandi, N. Using Chlorella Vulgaris and Iron Oxide Nanoparticles in a Designed Bioreactor for Aquaculture Effluents Purification. Aquac. Eng. 2020, 90, 102069. [CrossRef]

29. Ge, H.; Li, J.; Chang, Z.; Chen, P.; Shen, M.; Zhao, F. Effect of Microalgae with Semicontinuous Harvesting on Water Quality and Zootechnical Performance of White Shrimp Reared in the Zero Water Exchange System. Aquac. Eng. 2016, 72-73, 70-76. [CrossRef]

30. Peng, Y.-Y.; Gao, F.; Yang, H.-L.; Wu, H.-W.-J.; Li, C.; Lu, M.-M.; Yang, Z.-Y. Simultaneous Removal of Nutrient and Sulfonamides from Marine Aquaculture Wastewater by Concentrated and Attached Cultivation of Chlorella Vulgaris in an Algal Biofilm Membrane Photobioreactor (BF-MPBR). Sci. Total Environ. 2020, 725, 138524. [CrossRef] [PubMed]

31. Barnharst, T.; Rajendran, A.; Hu, B. Bioremediation of Synthetic Intensive Aquaculture Wastewater by a Novel Feed-Grade Composite Biofilm. Int. Biodeterior. Biodegrad. 2018, 126, 131-142. [CrossRef] 
32. Daneshvar, E.; Antikainen, L.; Koutra, E.; Kornaros, M.; Bhatnagar, A. Investigation on the Feasibility of Chlorella Vulgaris Cultivation in a Mixture of Pulp and Aquaculture Effluents: Treatment of Wastewater and Lipid Extraction. Bioresour. Technol. 2018, 255, 104-110. [CrossRef] [PubMed]

33. Andreotti, V.; Chindris, A.; Brundu, G.; Vallainc, D.; Francavilla, M.; García, J. Bioremediation of Aquaculture Wastewater from Mugil Cephalus (Linnaeus, 1758) with Different Microalgae Species. Chem. Ecol. 2017, 33, 750-761. [CrossRef]

34. Andreotti, V.; Solimeno, A.; Chindris, A.; Marazzi, F.; García, J. Growth of Tetraselmis Suecica and Dunaliella Tertiolecta in Aquaculture Wastewater: Numerical Simulation with the BIO_ALGAE Model. Water Air Soil Pollut. 2019, 230, 60. [CrossRef]

35. Liu, Y.; Lv, J.; Feng, J.; Liu, Q.; Nan, F.; Xie, S. Treatment of Real Aquaculture Wastewater from a Fishery Utilizing Phytoremediation with Microalgae. J. Chem. Technol. Biotechnol. 2019, 94, 900-910. [CrossRef]

36. Ding, Y.; Guo, Z.; Mei, J.; Liang, Z.; Li, Z.; Hou, X. Investigation into the Novel Microalgae Membrane Bioreactor with Internal Circulating Fluidized Bed for Marine Aquaculture Wastewater Treatment. Membranes 2020, 10, 353. [CrossRef]

37. Cardoso, L.G.; Duarte, J.H.; Costa, J.A.V.; de Jesus Assis, D.; Lemos, P.V.F.; Druzian, J.I.; de Souza, C.O.; Nunes, I.L.; Chinalia, F.A. Spirulina Sp. as a Bioremediation Agent for Aquaculture Wastewater: Production of High Added Value Compounds and Estimation of Theoretical Biodiesel. BioEnergy Res. 2020, 14, 254-264. [CrossRef]

38. Li, X.; Marella, T.K.; Tao, L.; Peng, L.; Song, C.; Dai, L.; Tiwari, A.; Li, G. A Novel Growth Method for Diatom Algae in Aquaculture Waste Water for Natural Food Development and Nutrient Removal. Water Sci. Technol. 2017, 75, 2777-2783. [CrossRef]

39. Michels, M.H.A.; Vaskoska, M.; Vermuë, M.H.; Wijffels, R.H. Growth of Tetraselmis Suecica in a Tubular Photobioreactor on Wastewater from a Fish Farm. Water Res. 2014, 65, 290-296. [CrossRef]

40. Han, W.; Mao, Y.; Wei, Y.; Shang, P.; Zhou, X. Bioremediation of Aquaculture Wastewater with Algal-Bacterial Biofilm Combined with the Production of Selenium Rich Biofertilizer. Water 2020, 12, 2071. [CrossRef]

41. Wicker, R.; Bhatnagar, A. Application of Nordic Microalgal-Bacterial Consortia for Nutrient Removal from Wastewater. Chem. Eng. J. 2020, 398, 125567. [CrossRef]

42. Sfez, S.; Van Den Hende, S.; Taelman, S.E.; De Meester, S.; Dewulf, J. Environmental Sustainability Assessment of a Microalgae Raceway Pond Treating Aquaculture Wastewater: From up-Scaling to System Integration. Bioresour. Technol. 2015, 190, 321-331. [CrossRef] [PubMed]

43. Guiza-Franco, L.; Orozco-Rojas, L.G.; Sánchez-Galvis, E.M.; García-Martínez, J.B.; Barajas-Ferreira, C.; Zuorro, A.; Barajas-Solano, A.F. Production of Chlorella Vulgaris Biomass on Uv-Treated Wastewater as an Alternative for Environmental Sustainability on High-Mountain Fisheries. Chem. Eng. Trans. 2018, 64, 517-522. [CrossRef]

44. Garcia-Martinez, J.B.; Urbina-Suarez, N.A.; Zuorro, A.; Barajas-Solano, A.F.; Kafarov, V. Fisheries Wastewater as a Sustainable Media for the Production of Algae-Based Products. Chem. Eng. Trans. 2019, 76, 1339-1344. [CrossRef]

45. Milhazes-Cunha, H.; Otero, A. Valorisation of Aquaculture Effluents with Microalgae: The Integrated Multi-Trophic Aquaculture Concept. Algal Res. 2017, 24, 416-424. [CrossRef]

46. Ansari, F.A.; Singh, P.; Guldhe, A.; Bux, F. Microalgal Cultivation Using Aquaculture Wastewater: Integrated Biomass Generation and Nutrient Remediation. Algal Res. 2017, 21, 169-177. [CrossRef]

47. Baird, R.; Bridgewater, L. Standard Methods for the Examination of Water and Wastewater, 23rd ed.; American Public Health Association: Washington, DC, USA, 2017.

48. Andersen, R.A.; Berges, J.A.; Harrison, P.J.; Watanabe, M.M. Appendix A-Recipes for Freshwater and Seawater Media. In Algal Culturing Techniques; Andersen, R.A., Ed.; Elsevier Academic Press: Burlington, MA, USA, 2005; pp. $429-538$.

49. Sanchez-Galvis, E.M.; Cardenas-Gutierrez, I.Y.; Contreras-Ropero, J.E.; García-Martínez, J.B.; Barajas-Solano, A.F.; Zuorro, A. An Innovative Low-Cost Equipment for Electro-Concentration of Microalgal Biomass. Appl. Sci. 2020, 10, 4841. [CrossRef]

50. Castellaños-Estupiñan, M.A.; Sánchez-Galvis, E.M.; García-Martínez, J.B.; Barajas-Ferreira, C.; Zuorro, A.; Barajas-Solano, A.F. Design of an Electroflotation System for the Concentration and Harvesting of Freshwater Microalgae. Chem. Eng. Trans. 2018, 64, 1-6. [CrossRef]

51. Garcia-Martinez, B.; Ayala-Torres, E.; Reyes-Gomez, O.; Zuorro, A.; Barajas-Solano, A.; Barajas-Ferreira, C. Evaluation of a Two-Phase Extraction System of Carbohydrates and Proteins from Chlorella Vulgaris Utex 1803. Chem. Eng. Trans. 2016, 49, 355-360. [CrossRef]

52. Barajas-Solano, A.F.; Gonzalez-Delgado, A.D.; Kafarov, V. Effect Of Thermal Pre-Treatment On Fermentable Sugar Production Of Chlorella Vulgaris. Chem. Eng. Trans. 2014, 37, 655-660. [CrossRef]

53. Mota, M.F.S.; Souza, M.F.; Bon, E.P.S.; Rodrigues, M.A.; Freitas, S.P. Colorimetric Protein Determination in Microalgae (Chlorophyta): Association of Milling and SDS Treatment for Total Protein Extraction. J. Phycol. 2018, 54, 577-580. [CrossRef]

54. Mishra, S.K.; Suh, W.I.; Farooq, W.; Moon, M.; Shrivastav, A.; Park, M.S.; Yang, J.W. Rapid Quantification of Microalgal Lipids in Aqueous Medium by a Simple Colorimetric Method. Bioresour. Technol. 2014, 155, 330-333. [CrossRef] [PubMed]

55. Hynstova, V.; Sterbova, D.; Klejdus, B.; Hedbavny, J.; Huska, D.; Adam, V. Separation, Identification and Quantification of Carotenoids and Chlorophylls in Dietary Supplements Containing Chlorella Vulgaris and Spirulina Platensis Using High Performance Thin Layer Chromatography. J. Pharm. Biomed. Anal. 2018, 148, 108-118. [CrossRef] [PubMed]

56. Rasoul-Amini, S.; Montazeri-Najafabady, N.; Shaker, S.; Safari, A.; Kazemi, A.; Mousavi, P.; Mobasher, M.A.; Ghasemi, Y. Removal of Nitrogen and Phosphorus from Wastewater Using Microalgae Free Cells in Bath Culture System. Biocatal. Agric. Biotechnol. 2014, 3, 126-131. [CrossRef] 
57. John, E.M.; Sureshkumar, S.; Sankar, T.V.; Divya, K.R. Phycoremediation in Aquaculture; a Win-Win Paradigm. Environ. Technol. Rev. 2020, 9, 67-84. [CrossRef]

58. Zuorro, A.; Leal-Jerez, A.G.; Morales-Rivas, L.K.; Mogollón-Londoño, S.O.; Sanchez-Galvis, E.M.; García-Martínez, J.B.; BarajasSolano, A.F. Enhancement of Phycobiliprotein Accumulation in Thermotolerant Oscillatoria sp. through Media Optimization. ACS Omega 2021, 6, 10527-10536. [CrossRef] [PubMed]

59. Lu, W.; Liu, S.; Lin, Z.; Lin, M. Enhanced Microalgae Growth for Biodiesel Production and Nutrients Removal in Raw Swine Wastewater by Carbon Sources Supplementation. Waste Biomass Valorization 2021, 12, 1991-1999. [CrossRef]

60. Do, C.V.T.; Nguyen, N.T.T.; Tran, T.D.; Pham, M.H.T.; Pham, T.Y.T. Capability of Carbon Fixation in Bicarbonate-Based and Carbon Dioxide-Based Systems by Scenedesmus Acuminatus TH04. Biochem. Eng. J. 2021, 166, 107858. [CrossRef]

61. Duan, Y.; Guo, X.; Yang, J.; Zhang, M.; Li, Y. Nutrients Recycle and the Growth of Scenedesmus Obliquus in Synthetic Wastewater under Different Sodium Carbonate Concentrations. R. Soc. Open Sci. 2020, 7, 191214. [CrossRef]

62. Cuéllar-García, D.J.; Rangel-Basto, Y.A.; Urbina-Suarez, N.A.; Barajas-Solano, A.F.; Muñoz-Peñaloza, Y.A. Lipids Production from Scenedesmus Obliquus through Carbon/Nitrogen Ratio Optimization. J. Phys. Conf. Ser. 2019, 1388, 012043. [CrossRef]

63. Barajas-Solano, A.F.; Guzmán-Monsalve, A.; Kafarov, V. Effect of Carbon-Nitrogen Ratio for the Biomass Production, Hydrocarbons and Lipids on Botryoccus Braunii UIS 003. Chem. Eng. Trans. 2016, 49, 247-252. [CrossRef]

64. García-Martínez, J.B.; Contreras-Ropero, J.E.; Urbina-Suarez, N.A.; López-Barrera, G.L.; Barajas-Solano, A.F.; Kafarov, V.; BarajasFerreira, C.; Ibarra-Mojica, D.M.; Zuorro, A. A Simulation Analysis of a Microalgal-Production Plant for the Transformation of Inland-Fisheries Wastewater in Sustainable Feed. Water 2022, 14, 250. [CrossRef]

65. Zuorro, A. Optimization of Polyphenol Recovery from Espresso Coffee Residues Using Factorial Design and Response Surface Methodology. Sep. Purif. Technol. 2015, 152, 64-69. [CrossRef] 